DOI: https://doi.org/10.32839/2304-5809/2019-11-75-37

УДК 681.51

Рура А.С., Тарахтій O.С.

Одеський національний політехнічний університет

\begin{abstract}
АНАЛІЗ ІСНУЮЧИХ СХЕМ РЕГУЛЮВАННЯ РІВНЯ В БАРАБАНІ ПАРОВОГО КОТЛА
\end{abstract}
Анотація. Рівень води в барабані парового котла є одним із найважливіших параметрів, що характеризуе надійність роботи котлоагрегату. Регулювання рівню води в барабані зводиться до підтримки матеріального балансу між подачею живильної води та витратою пари. До стабілізації рівню пред’являються дуже жорсткі вимоги, оскільки вихід рівню за допустимі межі може призвести до виникнення аварійних ситуащій або зупинки котлоагрегату. Вибір оптимальної системи регулювання рівня води в барабані парового котла дозволяе підвищити надійність та економічність роботи парового котла в стаціонарних та перехідних режимах роботи. В статті наведено аналіз існуючих схем автоматичного регулювання рівня води в барабані парових котлів. Наведені їх переваги та недоліки. Надано рекомендації щодо вибору оптимальної схеми регулювання рівня води в барабані.

Ключові слова: рівень живильної води, паровий котел, барабан, регулюваний параметр, автоматизована система регулювання.

Rura Andriy, Tarakhtii Olga Odessa National Polytechnic University

\title{
ANALYSIS OF EXISTING SCHEMES REGULATION OF THE LEVEL IN A STEAM BOILER DRUM
}

Summary. The water level in the boiler drum is one of the most important parameters that characterizes the reliability of the boiler. Adjusting the water level in the drum is to maintain a material balance between feed water and steam flow. Stabilization of the level is subject to very stringent requirements, as failure to reach the level can lead to accidents or stoppage of the boiler. Also, the dynamic properties of the steam generator by level are very unfavorable due to the manifestation of the phenomenon of "swelling" of the level. The main perturbations affecting the level of feed water in the boiler drum are the consumption of superheated steam or boiler load, variable feed water flow, change in feed water temperature, change in the flow rate of the boiler purge. In modern power boilers and medium power boilers, various circuits of automatic regulation of the feed water level in the drum are used. Each of these schemes has its own peculiarities when operating the boiler. Large-volume boilers with level stabilization allow the use of a single-circuit control circuit, unlike small-volume steam boilers. For this group of boilers, the three-impulse control scheme was most widespread. However, this scheme also has its disadvantages: the disappearance of one of the three signals or the decrease in the accuracy of the readings of one of the flowmeters of steam or feed water. The choice of the optimum system of regulation of water level in the drum of a steam boiler allows to increase reliability and economy of work of a steam boiler in stationary and transitional modes of operation. The article analyzes the existing schemes of automatic regulation of water level in the drum of steam boilers. Their advantages and disadvantages are given. Recommendations are given for choosing the best scheme for regulating the water level in the drum.

Keywords: feed water level, steam boiler, drum, adjustable parameter, automated control system.

П остановка проблеми. Рівень в барабані є одним 3 найважливіших регульованих параметрів правого котла, до якого виставляються жорсткі вимоги. Це обумовлено тим, що зниження або підвищенні рівня води в барабані парового котла суттево знижує ефрективність його роботи або може призвести до виходу з строю котлоагрегату в цілому [1, с. 225].

Також динамічні властивості даного об'єкту за каналами збурень і регулюючого впливу не мають самовирівнювання. В наслідок чого, система не може знаходитися в рівновазі і регульований параметр постійно коливається. Ще однією несприятливою особливістю динамічних властивостей парового котла за рівнем $є$ той фракт, що слід підтримувати рівень двофразного середовища. При цьому виникає так зване явище «набухання» рівню, яке негативно впливає на якість перехідних процесів регулювання $[2$, c. $67 ; 3$, c. 27$]$.

Аналіз останніх досліджень і публікацій. У зв'язку з вищесказаним, вибір оптимальної структури системи регулювання рівня і їі настройка $є$ дуже важливим фрактом, який дозво- лить забезпечити надійну роботу парового котла під впливом зовнішніх та внутрішніх збурень. А також може подовжити строк служби живильних насосів, регулюючої арматури та інших елементів парового котла [1, с. 227].

Мета статті. Головною метою ціеї роботи $\epsilon$ проведення порівняльного аналізу існуючих схем автоматичного регулювання рівню живильної води в барабані парового котла. Виявлення основних переваг та недоліків, надання рекомендацій щодо впровадження кожної з розглянутих схем.

Викладення основного матеріалу. Регулювання живлення парового котла зводиться до підтримки матеріального балансу між відводом пари і подачею живильної води. При порушенні цього балансу рівень в барабані котла починає змінюватись (рис. 1).

Зниження рівню до місця приєднання опускних труб циркуляційного контуру може призвести до порушення охолодження екранних труб. Наслідком чого може бути порушення міцності труб у місцях їх стиковки з корпусом барабану, а в найбільш тяжких випадках - перепален- 


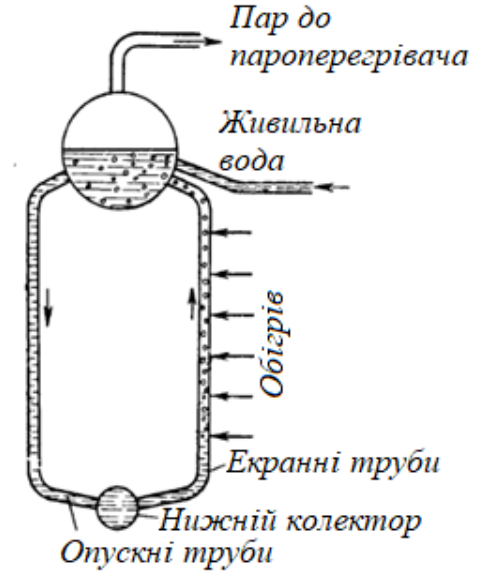

Рис. 1. Паровий котел як об'єкт регулювання рівня

Джерело: [3]

ню. Надмірне збільшення рівню призводить до зниження ефеективності внутрішньо барабанних сепараційних пристроїв та передчасному заносу солями пароперегрівача. А також спричинити важкі механічні пошкодження ротора і лопаток парової турбіни. Якість регулювання живлення парового котла визначаеться не лише точністю підтримки рівня на заданому значенні, але і рівномірністю подачі живильної води. Забезпечення барабану водою здійснюеться по одній i, рідше, двом ниткам трубопроводів живильної води, одна з яких слугуе резервною [3, с. $15 ; 4$, с. 221].

До того ж положення рівню за рахунок матеріального балансу витрат пари і живильної води забезпечуеться лише за умов стаціонарного режиму котла. В перехідних же режимах роботи на рівень води в барабані впливае велика кількість збурень, а саме: зміна витрати живильної води; зміна парового навантаження котла; зміна паропродуктивності при зміні тепловиділення в топці; зміна температури живильної води [3].

За кількістю сигналів, що надходять до регулятора рівня існують три основних принципи регулювання рівню: 1-імпульсний, 2-х імпульсний та 3-х імпульсний. Кожний з них має свої недоліки та переваги [3, с. $28 ; 4$, с. 222].

Схема одно-імпульсної автоматичної системи регулювання рівня води в барабані парового котла наведена на рис. 2.

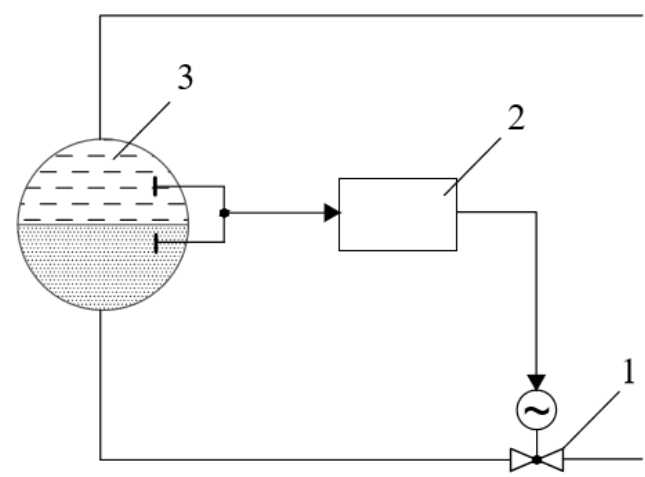

Рис. 2. Одно-імпульсна схема регулювання рівню: 1 - регулюючий клапан живильної води; 2 - регулятор живлення; 3 - барабан

Джерело: розроблено авторами за даними [4]
В наведеній схемі на вхід регулятора рівня 2 надходить лише сигнал від датчику вимірювання рівня в барабані 3. Після чого регулятор здійснюе вплив на регулюючий клапан 1 і змінюе витрату живильної води.

Однак оскільки барабанний котел як об'єкт регулювання має інтегральні властивості з присутністю неправдивої інформації у вигляді «набухання», то застосування одно-імпульсного інтегрального закону регулювання неможливо 3 умов стійкості системи. Пропорціональний закон регулювання дає добрі результати з позиції стійкості системи, але не припустимий через статичну похибку. Введення інтегралу до пропорційного закону дозволяе уникнути статичної похибки, однак не дає високої якості перехідних процесів регулювання. Оскільки ПІ-регулятор в наслідок явища «набухання» рівню в перехідних режимах роботи котла довгий час оказуе регулюючий вплив в бік, протилежний збереженню матеріального балансу між витратами пари та живильної води.

Таким чином, застосування одно-імпульсної АCP рівня води в барабані парового котла не забезпечуе необхідної якості регулювання, так як не враховуе основного збурення за витратою пари для споживача. Однак на практиці вона застосовуеться в котлах малої та середньої потужності (наприклад котли типу ДКВР), в яких за конструкцією барабану є великий запас живильної води і допустима статична похибка регулювання.

Головною перевагою одно-імпульсної системи регулювання є простота настройки, а також малий час перехідних процесів регулювання за умов використання П-закону регулювання.

Схема 2-імпульсної системи регулювання рівню води в барабані представлена на рис. 3. В неї використовуеться додатковий імпульс по основному збуренню - витраті пари на турбіну.

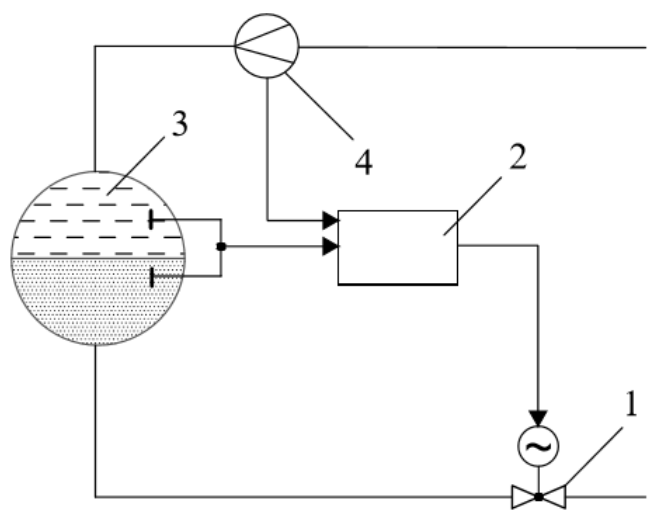

Рис. 3. Схема регулювання рівню - 2-імпульсна:

1 - регулюючий клапан живильної води; 2 - регулятор живлення; 3 - барабан; 4 - сигнал по витраті пара

Джерело: розроблено авторами за даними [4]

Введення додаткового імпульсу по витраті пари дозволяе підвищити якість регулювання і не допустити значного відхилення рівня води при збуренні за цим каналом. Недоліком 2-імпульсної схеми $є$ наявність статичної помилки, так як регулятор в цьому випадку стабілізуе НЕ рівень в барабані котла, а деяку алгебраїчну суму сигналів 
по рівню і витраті пари зі своїми ваговими коефіціентами, обумовленими при налаштуванні.

У перехідних режимах зміна рівню може відбуватися дуже швидко, тому регулятор живлення для забезпечення малих відхилень рівню повинен підтримувати постійність співвідношення витрат живильної води і пари. Цю задачу виконуе 3-імпульсний регулятор. Схема 3-імпульсної системи регулювання наведена на рис. 4.

Принцип роботи 3-імпульсної автоматичної системи регулювання полягае у наступному. Сигнали за витратою пари та живильної води вводяться в регулятор з протилежними знаками. У сталому режимі ці сигнали дорівнюють один одному, протилежні за знаком і, відповідно, компенсують один одного. Сигнал за рівнем води в барабані компенсуеться сигналом завдання.

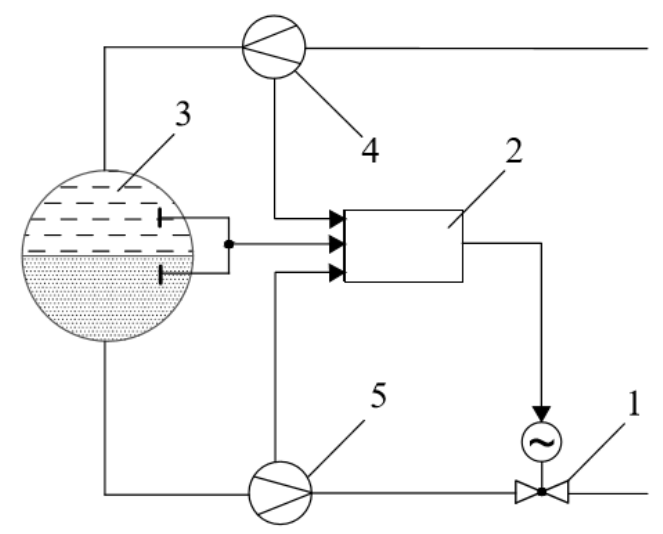

Рис. 4. Схема регулювання рівню-3-імпульсна: 1 - регулюючий клапан живильної води; 2 - регулятор живлення; 3 - барабан; 4 - сигнал по витраті пара; 5 - сигнал по витраті живильної води

Джерело: розроблено авторами за даними [4]

При зміні витрати пари миттево змінюеться відповідний сигнал на вході в регулятор і останній пропорційно змінюе витрату живильної води, не дочікуючись зміни рівню.

Недоліком 3-імпульсної схеми є наступні особливості: при зникненні будь-якого з трьох сигналів схема припиняе роботу, а при наявності розбіжності в показаннях витратомірів по живильній воді та перегрітому пару регулятор починає підтримувати рівень води в барабані, який дорівнюе сумі завдання і величини, пропорційної цій розбіжності (з'являеться статична помилка регулювання). Звичайно, методи «боротьби» з наведеними недоліками відомі. Так, при несправності витратоміра можна передбачити перехід регулювання з 3-імпульсної схеми на схему з жорстким зворотнім зв'язком (або зі зворотним зв'язком по витраті живильної води), але при цьому істотно знизиться якість регулювання. Якщо ж використовувати зникаючі сигнали по витраті перегрітої пари і живильної води, то це дозволить усунути статичну помилку регулювання, але в перехідних режимах роботи зникаючі сигнали витратомірів також призведуть до негативних наслідків - погіршення якості регулювання.

Також відома схема регулювання рівню води в барабані з використанням додаткового зникаючого сигналу за рівнем води [5, с. 75], яка наведена на рис. 5. Дана схема регулювання рівню живильної води в барабані котла позбавлена недоліків 3-імпульнсої схеми.

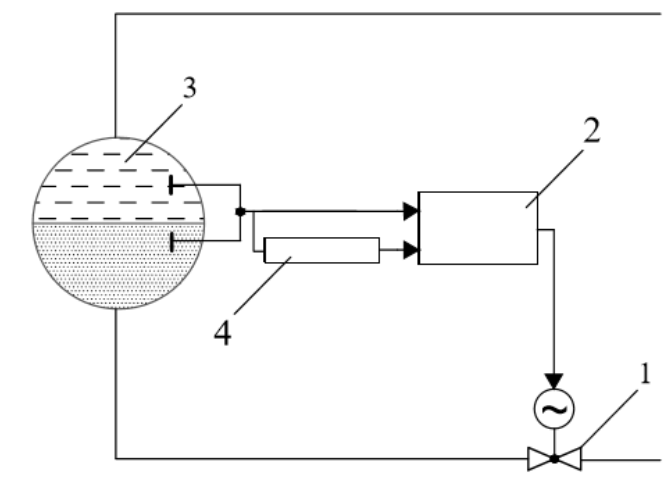

Рис. 5. Схема регулювання рівню 3 диференціатором: 1 - регулюючий клапан живильної води; 2 - регулятор живлення; 3 - барабан; 4 - диференціатор

Джерело: розроблено авторами за даними [5]

Принцип роботи АСР з дифреренціатором полягає в наступному. До регулятора рівня надходять два сигнали. Один сигнал надходить від датчику рівня, а другий є похідною від першого сигналу. Ця схема не має статичної помилки і використовує тільки один сигнал - за рівнем води в барабані, що підвищує надійність іï роботи. Схему з диференціатором, на відміну від 3-імпульсної, можна застосовувати для інших резервуарів, де потрібно підтримувати рівень при відсутності можливості контролю потоків середовища. Також дана схема швидше регулюе рівень до заданого значення i 3 меншим максимальним відхиленням параметра. Головним недоліком є складне налаштування такої схеми регулювання.

Висновки та пропозиції. Регулювання живлення котлів невеликої потужності зазвичай здійснюеться 1-імпульсними регуляторами, керованими датчиками зміни рівня води в барабані. В котлах середньої та великої паропродуктивності 3 малим водяним об'ємом застосовуються 2-імпульсні регулятори живлення за рівнем води і витратою пари, а також 3-імпульсні, що регулюють живлення парового котла за сигналами по рівню води, витраті живильної води та витраті пара. 3-імпульсні системи регулювання отримали найбільше розповсюдження на енергетичних парових котлах та котлах середньої потужності паропродуктивністю від 50 т/г і малим запасом води.

\section{Список літератури:}

1. Фам В.Д., Коновалов В.И. Исследование вариантов построения САР уровня в барабане парового котла. Сборник трудов ХІ МНПК студентов, аспирантов и молодых учашихся. 2013. С. 225-227.

2. Забиров Р.Р. Улучшение качества работы регулятора уровня в барабане котла. Совреленные наукоелкие технологии. 2007. № 1. С. 67-68.

3. Клюев А.С., Товарнов А.Г., Наладка систем автоматического регулирова-ния котлоагрегатов. Москва, 1970. $280 \mathrm{c}$. 
4. Плетнев Г.П. Автоматизация технологических процессов и производств в теплоэнергетике. Москва, 2007.352 с.

5. Слесь В.А., Григорьев В.А., Лисёнкин С.Д., Аглиулин С.Г., Чистяков Е.В. Сравнительный анализ различных схем регулирования уровня питательной воды в барабане котла. Безопасность Труда в Пролышленности. 2016. № 1. C. 74-77.

\section{References:}

1. Fam, V.D., \& Konovalov, V.I. (2007). Investigation of the options for building an ATS level in the drum of a steam boiler. Proceedings of the XI MNPK students, graduate students and young students. pp. 225-227.

2. Zabirov, R.R. (2007). Improving the quality of the level control in the boiler drum. Modern high technology, vol. 1, pp. $67-68$

3. Klyuev, A.S., \& Tovarnov, A.G. (1970). Adjustment of automatic control systems for boiler units. Moscow, 280 p.

4. Pletnev, G.P. (2007). Automation of technological processes and production in the power system. Moscow, $352 \mathrm{p}$.

5. Sles, V.A., Grigoriev, V.A., Lysyonkin, S.D., Agliulin, S.G., \& Chistyakov, E.V. (2016). Comparative analysis of various schemes for regulating the level of feed water in the boiler drum. Labor Safety in Industry, vol. 1, pp. 74-77. 